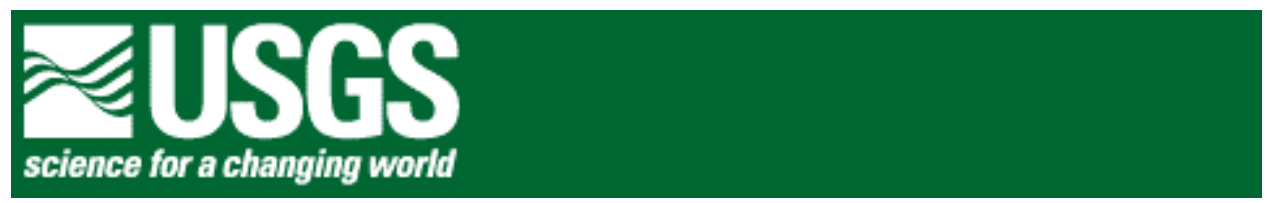

\title{
Examples of the utility of magnetic anomaly data for geologic mapping
}

Edited by Carol A. Finn ${ }^{1}$

With sections by

Mark Pilkington ${ }^{5}$, Richard Blakely ${ }^{2}$, Samuel Johnson ${ }^{1}$, William Cannon ${ }^{4}$, Mark Gettings ${ }^{3}$, and Walter Roest ${ }^{5}$

Open-File Report 02-400

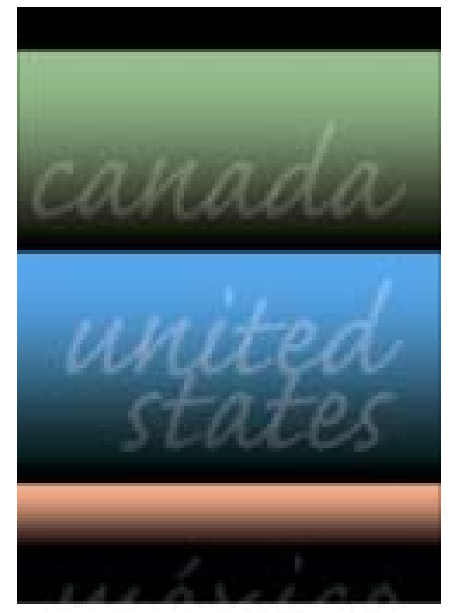

2002

This report is preliminary and has not been reviewed for conformity with U.S. Geological Survey editorial standards or the North American Stratigraphic Code. Any use of trade, firm, or product names is for descriptive purposes only and does not imply endorsement by the U.S. Government

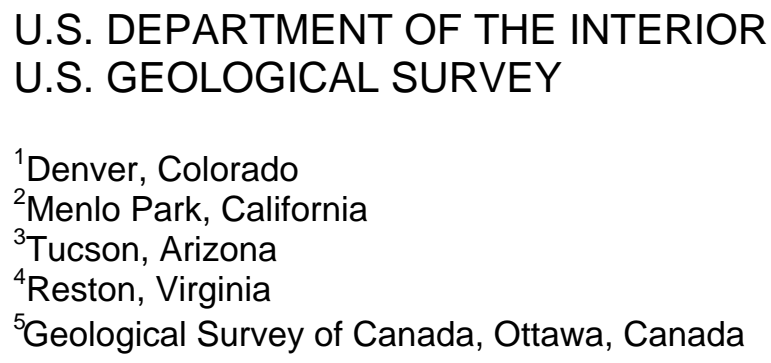


Understanding the regional geology of the North American continent can provide information useful for a wide variety of applications such as mineral and energy resource assessments, earthquake and landslide hazards, and hydrologic and environmental studies. The following case studies illustrate some applications of various high-resolution magnetic surveys ( $<800 \mathrm{~m}$ line spacing) contained in the upgraded North American magnetic anomaly map (fig. $1)$.

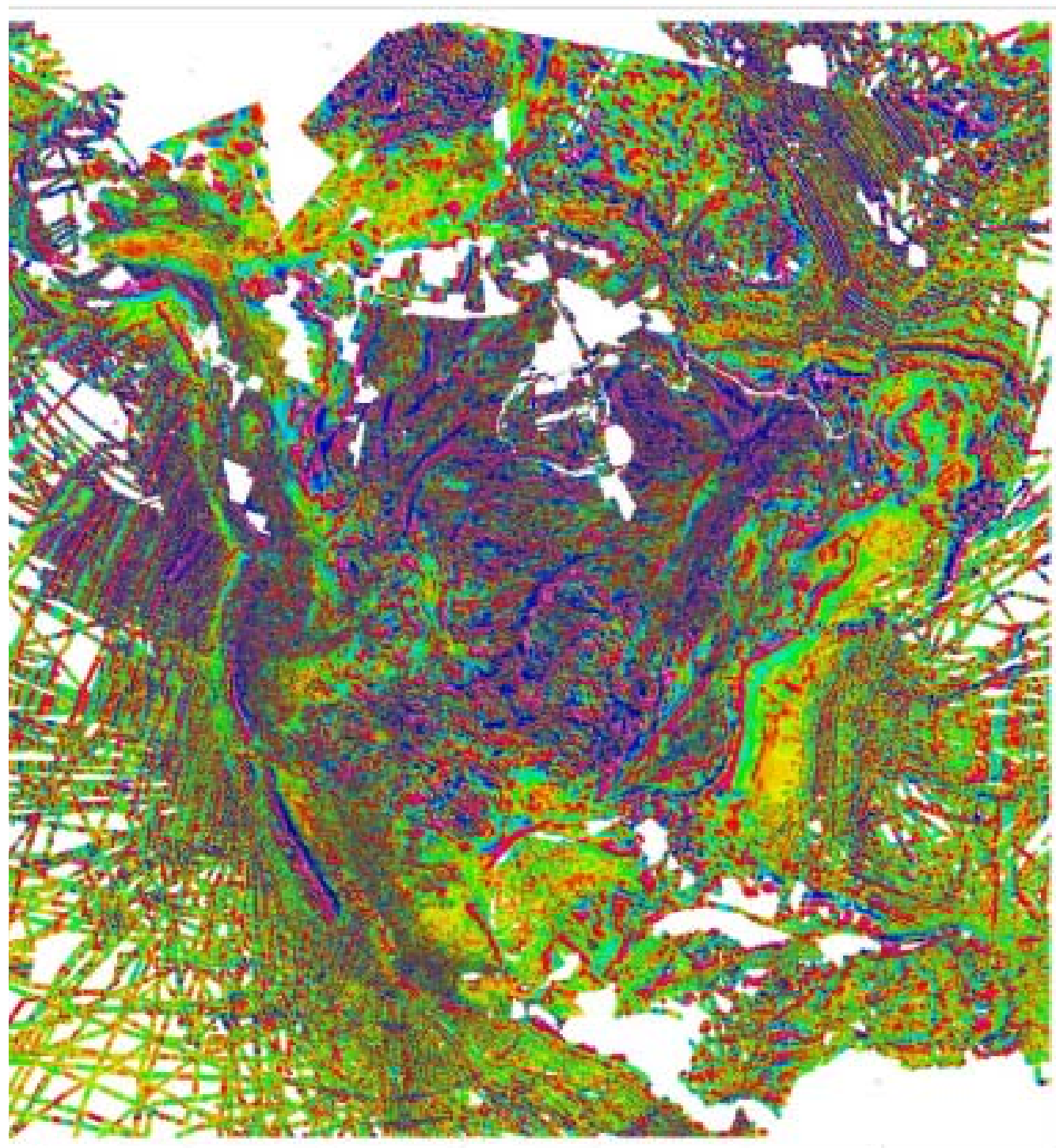

Figure 1. Magnetic anomaly map of North America (North American Magnetic Anomaly Group, 2002). 


\section{Mapping Precambrian basement in Alberta, Canada by Mark Pilkington}

Although low-resolution magnetic compilations have been used to map regional geology, the modern high-resolution data available since the previous North American magnetic compilation (Committee for the Magnetic-Anomaly Map of North America, 1987) provides a clearer view of completely obscured rocks, allowing much finer divisions of provinces (Pilkington and others, 2000). As magnetic field compilations extend to greater scales, they are used increasingly to tie existing isolated interpretations or maps together through continuous data coverage, provide continent-scale perspectives on geologic structure and evolution, and extend geological mapping of exposed (particularly Precambrian basement) regions into sedimentcovered areas. A fundamental building block in these interpretations is the geophysical domain, distinguished on the basis of anomaly trend, texture, and amplitude. Where basement is exposed, these domains often coincide with lithotectonic domains, geologic provinces, or cratons, depending on the scale of investigation. Delineating areas of magnetic anomalies having similar characteristics is intended, therefore, to isolate areas of crust having similar lithological, metamorphic, and structural character, and possibly, history. Anomaly trends may indicate the type of deformation undergone: for example, sets of parallel, narrow curvilinear anomalies may attest to penetrative deformation whereas broad ovoid anomalies might suggest relatively undeformed plutons. The average anomaly amplitude within a domain reflects its bulk physical properties. For example, calc-alkaline magmatic arcs generally are marked by belts of highamplitude positive magnetic anomalies while greenstone terranes commonly are associated with subdued magnetic fields. Additionally, where anomaly trends show abrupt changes in direction at domain boundaries, the relative age of the adjacent domains may also be inferred.

An example of this type of approach to interpreting magnetic data is work done on the Western Canada Sedimentary Basin (WCSB) in Alberta and northeastern British Columbia, Canada. The general shape of the sedimentary cover in the WCSB approximates a westwardthickening wedge that increases in thickness from zero in northeast Alberta to more than $5 \mathrm{~km}$ in western Alberta. The sedimentary rocks that occupy the basin are only weakly magnetic, so the observed magnetic field is primarily due to variations in magnetization of the basement (crystalline) rocks that underlie the basin fill. As the sediment thickness in the WCSB increases, magnetic anomalies caused by magnetized sources in the basement rocks attenuate and broaden.

The Precambrian basement of the WCSB were subdivided into domains based on their characteristic magnetic field patterns and the coincidence of similar dates of drill cores from basement intersections recovered during hydrocarbon exploration (fig. 2). Corroboration of their interpretation was provided by analogy with magnetic signatures of exposed geologic subdivisions of the Canadian Shield. On the basis of the subdivision, tectonic models for the evolution and assembly of the domains were inferred. The assumption was made that the configuration of the basement observed today is the result of the amalgamation of many separate domains brought together by the plate tectonic processes of subduction and collision. Several of the domains such as Ksituan (Ks) and Fort Simpson (F), which have the highest amplitude anomalies, are interpreted as magmatic arcs, consisting of plutonic rocks such as granites, which were formed over subduction zones. Domains with intermediate amplitude anomalies such as Wabamum (W), Lacombe (L), and Medicine Hat $(\mathrm{Hb})$ suggest the presence of basic and granitoid rocks and may indicate accreted terranes. Within some of the moderately magnetic 
domains are areas of weakly magnetic lithologies that produce no magnetic anomalies. The narrower regions of magnetic lows such as the Thorsby (T), Kiskatinaw (K), and Vulcan (Hv) domains are interpreted as resulting from demagnetization effects accompanying collision. Since demagnetization zones are limited in areal extent, the wider, more extensive magnetic lows of the Chinchaga $(\mathrm{C})$ and Hottah $(\mathrm{H})$ domains likely result from a combination of boundary demagnetization and a lower bulk magnetization level of crustal lithologies present.

Figure 2. Magnetic field over Alberta and northeastern British Columbia, Canada. Interpreted domains are outlined in black and labelled.

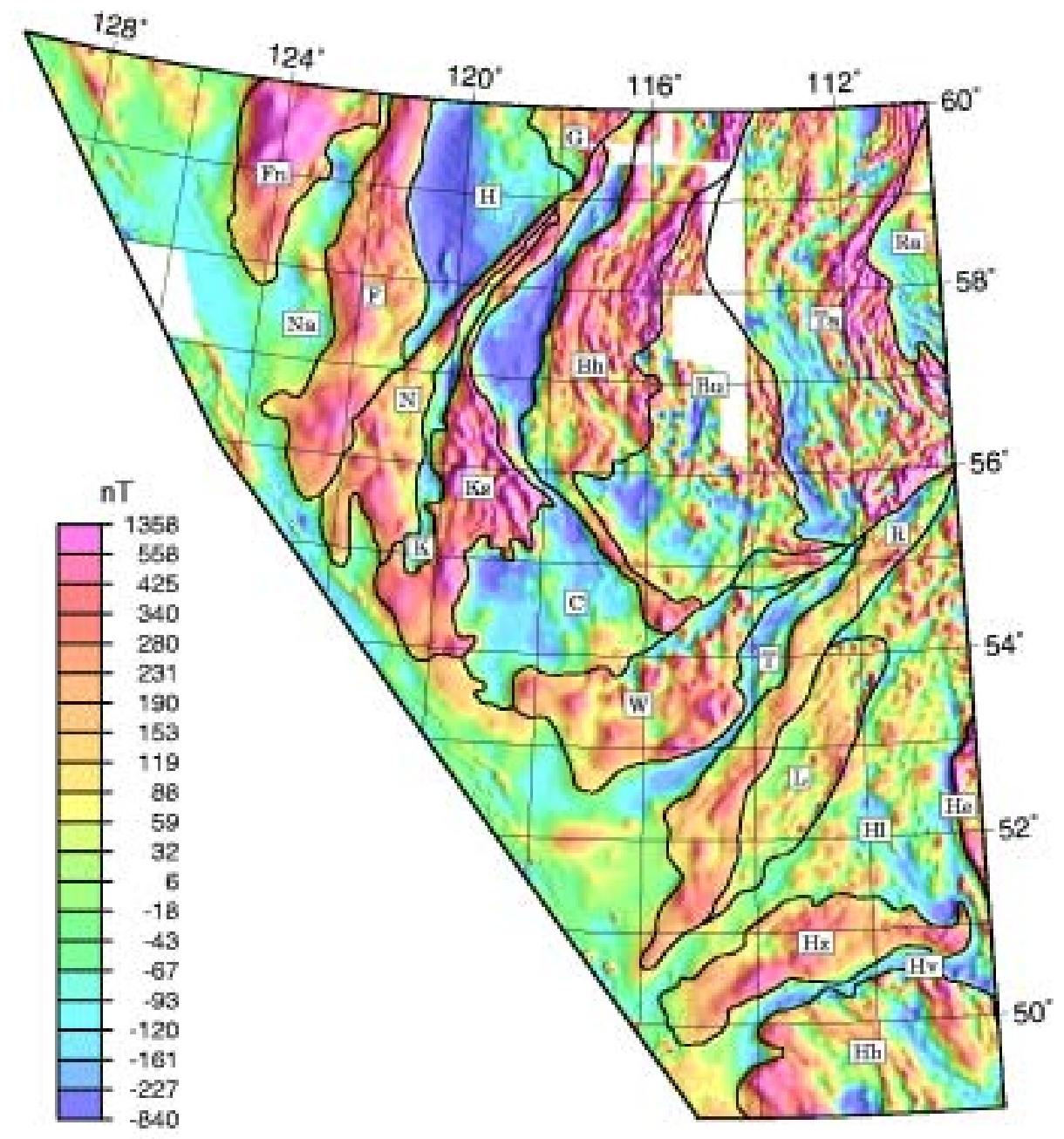




\section{Mapping Precambrian rift structures in the mid-continent, US by William Cannon}

In addition to mapping regional geologic domains, the compiled magnetic data can be used to map local geologic units. In this example, the local geology of part of the $1.1 \mathrm{Ga}$ Midcontinent rift is revealed by the magnetic data (taken from Cannon and others, 2001). Although the general character of the Midcontinent rift has been known for many years, details of its geology and origin have been obscure because most of it is buried beneath a veneer of younger (Paleozoic) sedimentary rocks. The rift is an alignment of deep, fault-bounded troughs (grabens) filled with continental flood basalt and related intrusions, accentuated by post-extensional thermal subsidence of the lithosphere, which formed a somewhat broader basin now filled mostly with continental fluvial sediments. The grabens were partly inverted, beginning concurrently with sedimentation, so that the basalts were thrust upward through the overlying sedimentary rocks to form the present day horsts, such as the St. Croix.

The geophysical signature of the St. Croix horst reflects this structure (fig. 3a). The inverted graben produces very intense positive gravity and magnetic anomalies, because it is filled with a great thickness of relatively dense and magnetic basalt. Steep gradients in both the magnetic and gravity field along bounding faults are caused by steep fault contacts between the thick sequence of basalt and related mafic intrusive rocks of the horst and sedimentary rocks of the flanking basins, such as the Emerald basin on the east and Bayfield basin on the west (fig. $3 b)$.

Contrasting magnetic properties between the numerous basalt flows allows individual flows or packages of flows to be traced for long distances, nearly 100 kilometers in some cases. The aeromagnetic data show that the basalt sequences form arcuate patterns in which flows commonly terminate against these faults at high angles (such as points $\boldsymbol{A}, \boldsymbol{B}$, and $\boldsymbol{C}$, fig. 3b). These truncations are likely to be original terminations of flows where they abutted against fault scarps of an actively subsiding graben. The magnetic data also provide the first clear indication of unconformities in the volcanic section. Two discontinuities along which younger flows truncate older flows at a low angle are shown at points $\boldsymbol{D}$ and $\boldsymbol{E}$. In the north, a relatively young series of flows, the Minong volcanics (informal name), can be traced around the gently northeast-plunging Ashland syncline. On the east limb of the syncline the Minong volcanics comprise the entire exposed volcanic section. The basal Minong flows can be traced by their magnetic anomaly around the keel of the syncline and onto the north limb where they appear to be underlain unconformably by a thick series of older basalt flows, informally called the Clam Falls volcanics. Within these volcanics, numerous west- and northwest-trending linear magnetic anomalies cut the magnetic pattern produced by the flows. These linear anomalies all terminate against either the Pine fault on the west or against the inferred mafic intrusion along the Hastings-Lake Owen fault and are related to dikes. 

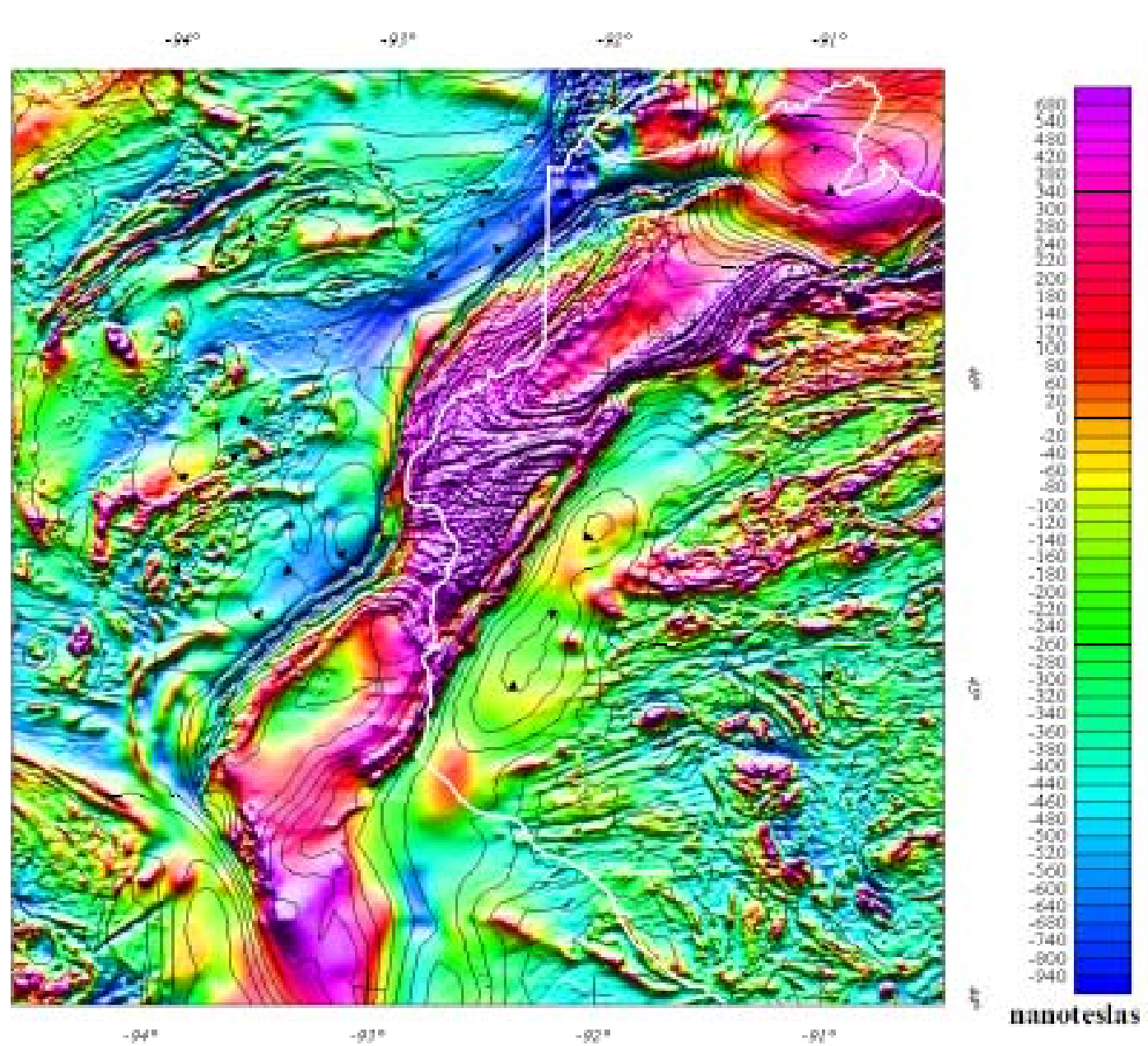

Aeromagnetic Map of the Midcontinent Rift Area

Minnesota \& Wisconsin

Overlay: 10 mgal Bouguer Gravity Contours
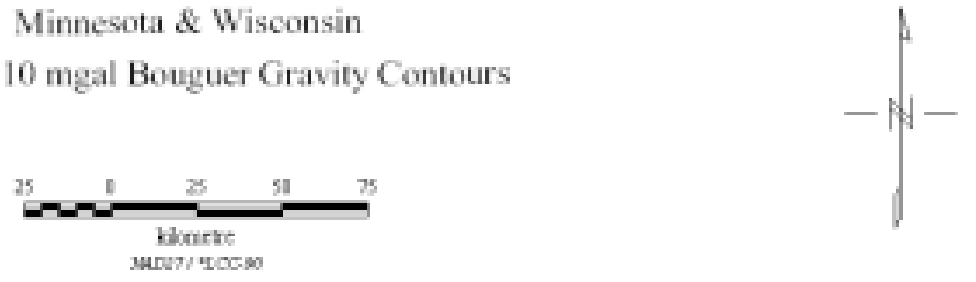

Figure 3a. Aeromagnetic map of the mid-continent region, Minnesota and Wisconsin. 


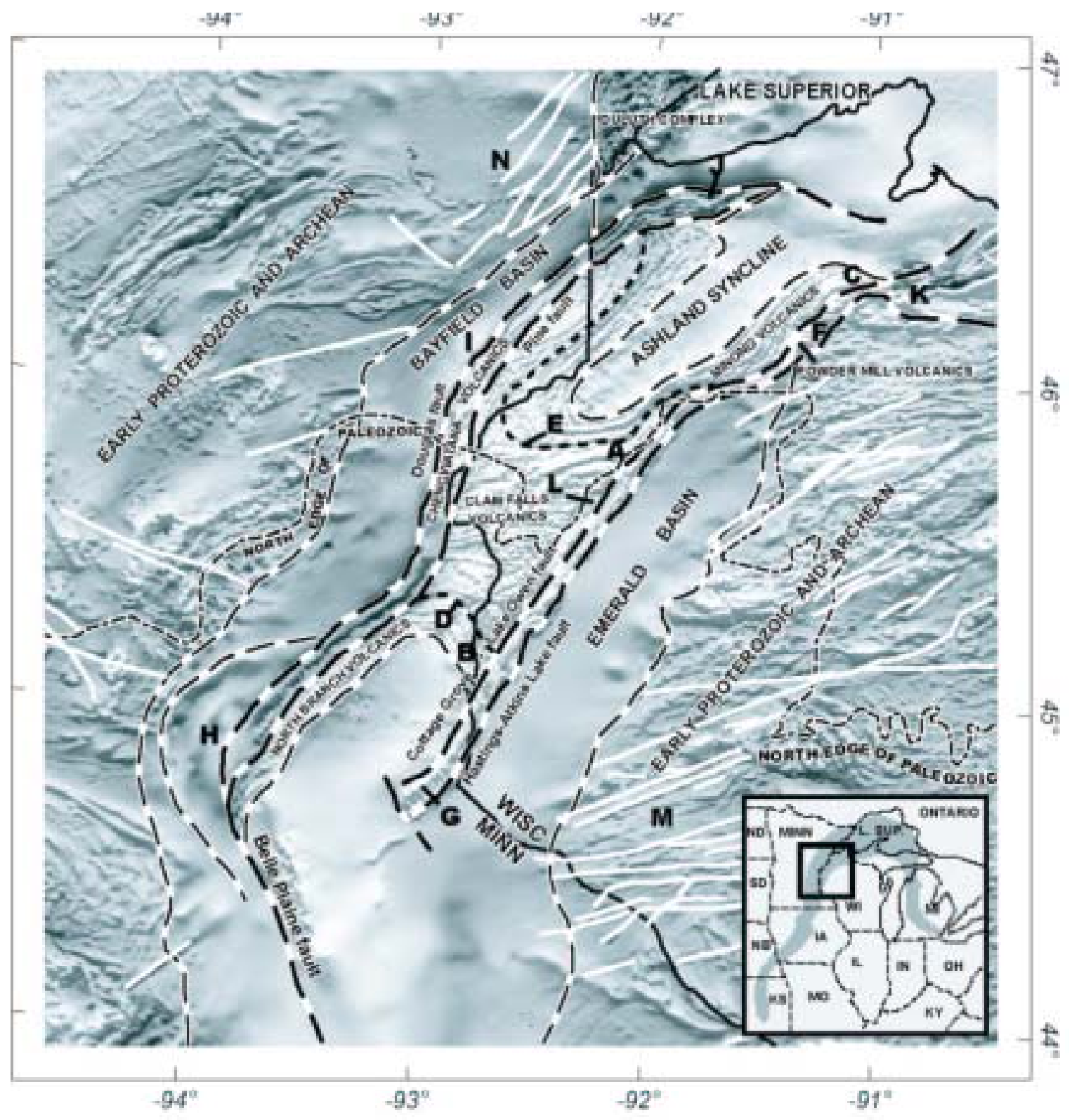

Figure 3b. Gray-shade aeromagnetic map of the mid-continent region, Minnesota and Wisconsin, showing major geologic units. 
Aeromagnetic Anomalies in Earthquake Hazard Investigations: An Example from the CanadianU.S. Border by Richard J. Blakely and Samuel Y. Johnson

Urban areas of the northwestern United States and southwestern Canada (Cascadia) face a diverse set of earth hazards ultimately caused by subduction of the Juan de Fuca plate beneath North America (Wells and others, 1998). Very large earthquakes $(M \geq 9)$ are expected offshore every 500 years, on average, as the two plates slip abruptly past one another. Earthquakes up to M 7 occur more frequently within the subducting slab as it passes through critical depths beneath the Cascadia forearc. A third class of earthquakes occurs within the crust of the North American plate, along crustal faults actively responding to the stresses of plate tectonics. Little is known about the details of Cascadia crustal faults because repeated glacial events have erased most of their topographic expression and covered many of their geologic relationships. On the other hand, geophysical and geologic studies have identified fault zones beneath or near many of the population centers of the Cascadia forearc, notably the major cities of Vancouver, Seattle, and Portland. Understanding the length, three-dimensional characteristics, and rate of earthquake recurrence of these crustal faults is key to understanding and mitigating their hazards.

Although young deposits, water, and vegetation cover much of the Cascadia forearc, it is also underlain at relatively shallow depth by igneous rocks of diverse origins. The contrasting physical properties of these rocks are ideal for geophysical studies, and recent seismic reflection surveys (e.g., Johnson and others, 1996), tomographic inversions (e.g., Brocher and others, 2001), and aeromagnetic mapping (e.g., Blakely and others, 2002) have contributed significantly to our understanding of Cascadia geology and tectonics. In particular, high-resolution aeromagnetic data from the Puget Lowland (Blakely and others, 2002) and Willamette Valley (Blakely and others, 2000) have proven a useful proxy for bedrock geology, thus revealing faults often concealed.

The Devil's Mountain fault and neighboring faults in Washington and British Columbia serve as an excellent example (fig. 4). Johnson and others (2001) recently described the geologic and geophysical setting of the Devil's Mountain fault, which extends west from the Cascade Range foothills for more than $125 \mathrm{~km}$ to Vancouver Island. High-resolution seismic-reflection profiles and its association with northwest-trending en echelon structures both north and south suggests that the Devil's Mountain fault is an oblique, left-lateral, north-side-up, transpressive structure with steep $\left(45^{\circ}\right.$ to $\left.75^{\circ}\right)$ northward dip. Together with the Strawberry Point and Utsalady Point faults, Johnson and others (2001) estimated a cumulative slip rate in excess of 0.5 $\mathrm{mm} / \mathrm{y}$.

Prominent aeromagnetic anomalies are associated with the Devil's Mountain fault (fig. 4). A pattern characterized by high-amplitude, northwest-striking anomalies northwest of the fault juxtaposed against subdued anomalies to the south is consistent along the length of the fault, a distance in excess of $100 \mathrm{~km}$. Some anomalies north of the fault are associated with exposures of pre-Tertiary ophiolites, and similar rocks are the likely source of most of these high-amplitude anomalies. The subdued pattern south of the fault, on the other hand, reflects thick sections of relatively nonmagnetic pre-Tertiary and Tertiary sedimentary rocks.

In many cases, magnetic anomaly gradients correspond closely with faulted stratigraphy along the Devil's Mountain fault and along other faults to the north and south, as seen in highresolution seismic-reflection profiles (Johnson and others, 2001). The magnetic anomalies thus permit extrapolation of fault traces between and beyond widely spaced seismic transects. This 
symbiotic interpretation of high-resolution seismic-reflection and aeromagnetic data is particularly well displayed in three zones of north-west striking faults north of the Devil's Mountain fault: in Rosario Strait, south of Lopez Island, and in the mouth of Haro Strait (fig. 4). Although the westward projection of the Devil's Mountain fault passes south of Victoria and connects with the Leech River and/or San Juan faults on Vancouver Island, the Leech River and San Juan faults do not appear to be active at present. Johnson and others (2001) suggested that strain on the Devil's Mountain fault may instead be transferred to northwest-striking structures in Haro Strait prominently displayed in aeromagnetic anomalies (fig. 4), which continue $40 \mathrm{~km}$ northwestward, passing north of Victoria.

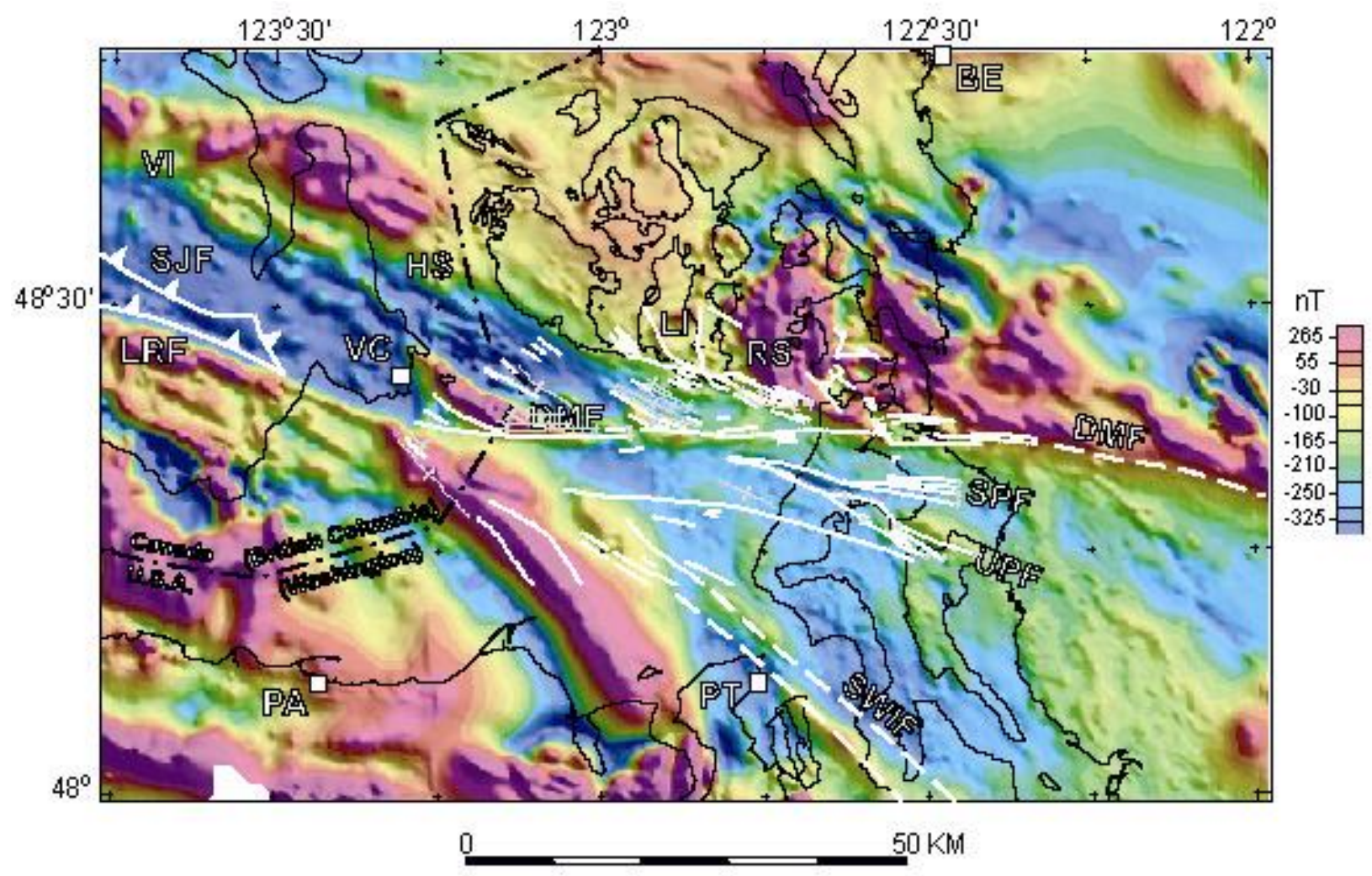

Figure 4. Aeromagnetic anomalies associated with the Devil's Mountain fault and neighboring faults and structures, Washington and British Columbia. Color shaded-relief indicates total-field magnetic anomaly from various aeromagnetic surveys conducted by the U.S. Geological Survey and Canadian Geological Survey. Illumination from northeast; color intervals based on equal area algorithm. Black lines indicate coastlines, white lines are faults. Faults shown as light dotted lines are from Johnson and others (2001). BE, Bellingham; HS, Haro Strait; LI, Lopez Island; PA, Port Angeles; PT, Port Townsend; RS, Rosario Strait; VC, Victoria; VI, Vancouver Island. DMF, Devil's Mountain fault; LRF, Leech River fault; SJF, San Juan fault; SPF, Strawberry Point fault; SWIF, southern Whidbey Island fault; UPF, Utsalady Point fault. 
Applications of aeromagnetic data to water and mineral resource problems along the ArizonaSonora international border by Mark E. Gettings

Aeromagnetic data provide an indirect means to identify mineral and hydrologic resources. New developments in data acquisition, accuracy and processing, however, now make it possible to extract useful information from some of the subtleties of the magnetic anomaly field related to geologic structures controlling the location and shape of mineral deposits or aquifers. Two benefits of the North American Magnetic Database Compilation will be to facilitate studies of these features in areas where data quality and quantity is sufficient, and to encourage comparative studies between different regions. One such region is the Arizona, USA, and Sonora, Mexico, border area, where high quality data are available in a region where both mineral deposits and water resources are priority issues.

Both improved data resolution and advances in methods and techniques have made traditional analysis of potential field data such as filtering, field continuation, depth to source, and source edge location calculations more reliable and less difficult to perform. In addition, a new subject of research in aeromagnetic data interpretation is the definition and measurement of the "texture" of the magnetic anomaly field. It has been recognized for many years that areas of different lithology often display a distinct appearance or texture on a map of aeromagnetic anomalies, and extending lithologies beneath cover based on aeromagnetic signatures has been a common but empirical procedure. The recognition that the distribution of aeromagnetic anomalies and magnetic sources are fractal in nature (Pilkington and Todoeschuck, 1993) has led to new techniques for measuring textural properties. Two such measures that are useful in mapping lithology in the subsurface are the number of anomaly peaks and troughs per kilometer and the "length" of the magnetic anomaly data per kilometer along the flight line (Gettings, 1999, 2002). These measures are calculated within a moving window along the flight line data and are useful for mapping lithology if it is not too deeply buried.

\section{Mineral Resource applications}

Similar high-frequency magnetic anomalies (area 3 , fig. $5 b$ ) and patterns of textural measures (area 3, Figs. $5 \mathrm{c}$ and d) identify the eastward continuation of a volcanic field (area 2, fig. 5a-d) beneath basin fill and the buried as well as the exposed portion of the Pajarito caldera (Lipman and Sawyer, 1985) (area 4, fig. 5). Part of the rocks of the exposed portion of the caldera $(\mathrm{Kr}$, fig. $5 \mathrm{a}$ ) were identified as having high potential for undiscovered polymetallic vein deposits in a mineral resource appraisal of the area (duBray, 1996) (outlined in blue, fig. 5a). The downfaulted and buried remainder of the caldera structure appears as a pattern of noisy (many peaks and troughs, area 4, fig. 5c), low-amplitude (area 4, fig. 5d) magnetic anomalies (area 4, fig. 5b). Depth estimates to magnetic source for the buried part of the caldera are of the order of $100 \mathrm{~m}$ or less (Phillips, 2002) and so the area of the buried caldera must also be considered as having high potential for undiscovered polymetallic vein deposits (outlined in red on fig. 5a).

\section{Hydrologic applications}

The principal aquifer in many basins lies in unconsolidated fill. Therefore, the thickness of the fill provides a maximum bound on the potential size of the aquifer. Using the combination 
of gravity and magnetic data to constrain models of basin shape makes it possible to estimate the depth of unconsolidated basin fill overlying a more dense, cemented, but mostly nonmagnetic fill in southwest basins (e.g. Gettings and Houser, 1997). In addition, volcanic rocks within the basin fill (area 3, fig. 5b-d) may affect water quality and constitute a significant hydrologic reservoir. Depending upon their composition, volcanic rocks, particularly rhyolitic tuffs, may react with ground water and act as a source of metals (for example, iron, lead, mercury, etc.) and other complexes (for example, arsenates and phosphates). Thick sequences of volcanic flows are often highly permeable due to vesicularity, fractures, and rubble and tephra zones between flows making such sections a good aquifer.

High resolution aeromagnetic data often is able to resolve small anomalies (1-10 nT) caused by magnetic detritus in the basin fill and can be useful in resolving structure and provenance within the fill (Grauch, 1997; Grauch and others, 2001). For example, noisy (area 1, fig. 5c) low amplitude (area 1, fig. 5d) magnetic textures can be produced by a paleo-stream channel filled with magnetic material, particularly as it correlates closely with the young magnetic gravels of the Santa Cruz River bed (Qg, fig. 5a). The source of the material seems to be coming from the side canyon to the west at the southern (upstream) end of the anomalous area. It is notable that this feature, and the caldera (area 4, fig. 5) are not prominent on the aeromagnetic anomaly map (fig. 5b). This occurs for two reasons: first, the gridding process is a low pass filter with a cutoff half wavelength equal to the grid interval so that short wavelength anomalies are lost; and second, the color table used in many display programs is often nonlinear so that fine anomaly structure at the upper and lower ends of the range is not well represented. Features such as buried channels and volcanic fields identified from these analyses can converted to parameters useful in 3-dimensional models of ground-water flow. 


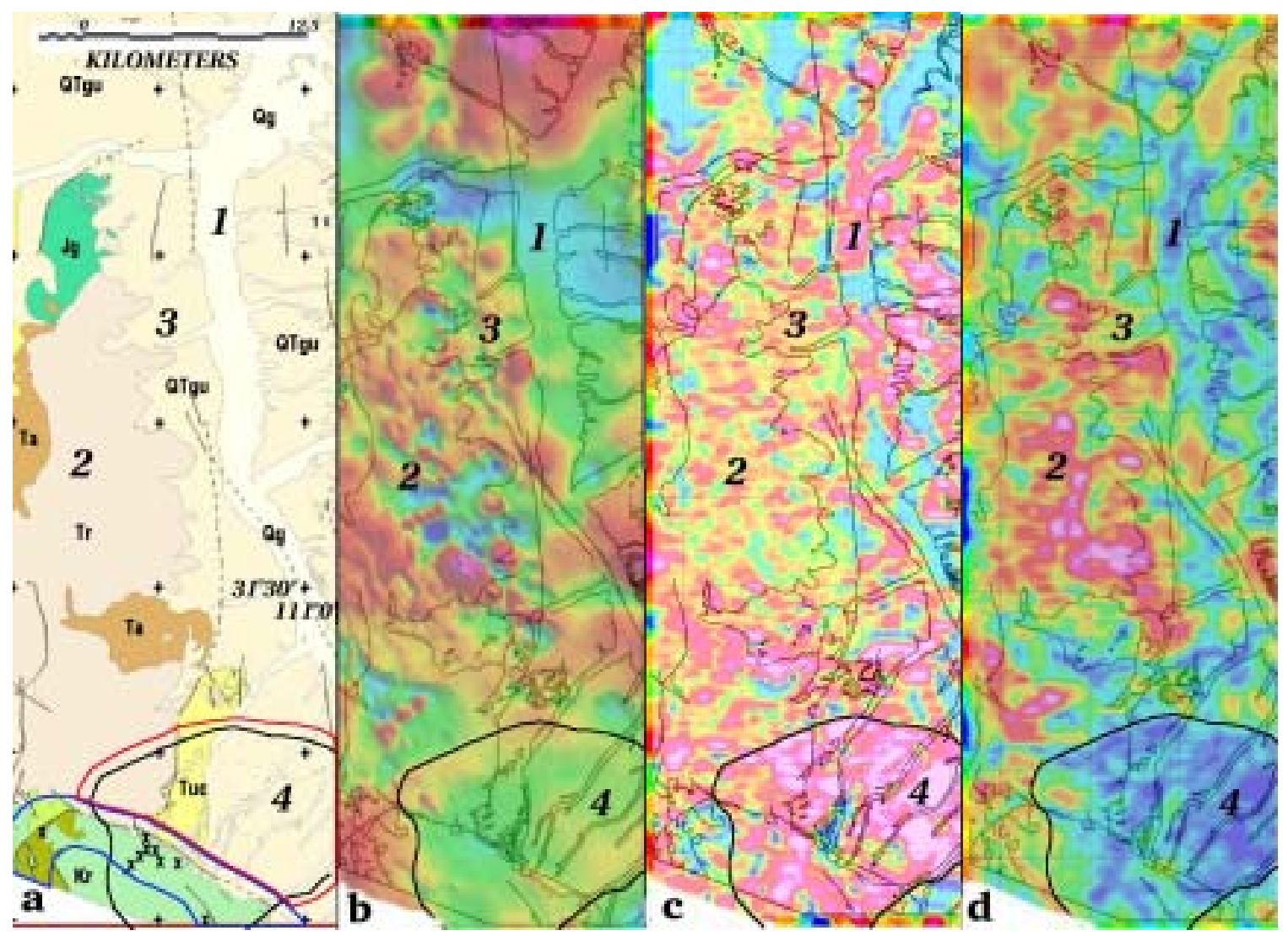

Figure 5. Example of high resolution aeromagnetic data and textural measures from near Nogales, Arizona. Geologic map (a) shows Jurassic granite (Jg), Cretaceous rhyolite (Kr), Tertiary andesite (Ta) and rhyolite (Tr), Tertiary conglomerate (Tuc), Tertiary and Quaternary basin fill (Qtgu), and Quaternary gravel (Qg). Symbols " $\mathrm{X}$ " near the bottom of the figure locate mines and prospects; blue line delimits area of high potential for undiscovered polymetallic vein deposits; red line shows its extension into the subsurface from analysis of aeromagnetic data in panels $\mathrm{c}$ and $\mathrm{d}$. Panel $\mathrm{b}$ is the shaded relief aeromagnetic map overlain with the line work from (a); warmer colors indicate more positive magnetic anomaly. Panel $\mathrm{c}$ is the number of peaks and troughs $/ \mathrm{km}$ along the flight lines (east-west), and panel $\mathrm{d}$ is the magnetic data "length" $/ \mathrm{km}$ along the flight lines. Warmer colors in (c) indicate more peaks and troughs/km or "noisier" magnetic anomalies, while warmer colors in (d) indicate more intense (larger amplitude) anomalies $/ \mathrm{km}$. Areas labeled 1-4 are discussed in the text; flight line spacing and terrain clearance is $250 \mathrm{~m}$.

\section{Marine Magnetic Anomalies In Labrador by Walter Roest}

The increase in resolution of magnetic surveys is not restricted to continental areas. This example illustrates the utility of uniformly collected marine magnetic data in the Labrador Sea region of northeastern Canada. The oceanic regions display relatively simple patterns of parallel anomalies, whereas continental regions are much more complex. One of the reasons for this difference is that ocean crust is much younger than most continents - the oldest known ocean floor is about 200 million years old - and is formed by the relatively simple process of sea floor spreading. By comparing magnetic 
anomalies cause by sea floor spreading with the geomagnetic reversal time scale, the age of the oceanic crust can be determined. This indirect method of dating ocean floor has been very successful and is instrumental in deciphering the history of the ocean basins. Several drill-holes, drilled as part of the international Ocean Drilling Program, have confirmed the ages obtained from magnetic anomalies. Figure 6 shows a color image of the age of the ocean floor derived from the magnetic anomalies and the geomagnetic reversal time scale and shaded with the topography of land and ocean. In this image, cool colors represent the oldest ocean floor and warmer colors the youngest. Along the east coast of North America, the age of the ocean floor adjacent to the continental margin gets progressively younger from south to north. This indicates that sea floor spreading started in the south, with the break-up between Africa and North America, and gradually propagated northward.

A period of continental stretching usually precedes sea floor spreading. During this period, continental crust is thinned until it eventually breaks. This process formed the continental margins off Canada's east coast (light gray regions, fig. 6). These regions contain large sedimentary basins that bear oil and gas, such as the Jeanne d'Arc basin, the location of the Hibernia oil field. Magnetic anomalies in these areas reflect basement structure and deformation history, and can be used to locate potential regions of economic hydrocarbon reserves.

Offshore magnetic surveys are largely done by ship. A magnetometer is towed behind the ship at a distance large enough to ensure that the magnetic effect of the ship on the sensor is negligible. Unlike aeromagnetic surveys, most shipborne surveys are not designed in a regular fashion, but rather, the observations are made along transit lines. One exception is a series of systematic surveys, conducted by the Geological Survey of Canada, along Canada's east and west coast, designed to get systematic coverage of the continental margins and the adjacent ocean floor.

The Labrador Sea is an example of an ocean basin where marine magnetic anomalies were essential in understanding its formation. The Labrador Sea is a relatively small ocean basin that was formed when Greenland moved away from North America during the late Cretaceous and early Tertiary (fig. 6). Magnetic anomalies caused by sea floor spreading in the central part of the basin are quite well developed and indicate ages ranging from $60 \mathrm{Ma}$. to as young as $37 \mathrm{Ma}$., when sea floor spreading stopped and Greenland became part of the North American tectonic plate. A controversy exists about the age of the oldest sea floor spreading anomalies recorded in the oceanic crust in the Labrador Sea. Srivastava and Roest (1999) have identified anomaly 34 (85 Ma) as the first lineation and interpreted that rifting of the Labrador Sea started about $95 \mathrm{Ma}$. Others, however, have argued on the basis of seismic reflection data that true sea floor spreading started later and that a large part of the basin is in fact underlain by stretched continental crust. It is also possible that part of the region is in fact exposed mantle peridotite, based on unusual seismic velocities. Working with a variety of data sets, including magnetic and gravity anomalies and seismic reflection profiles, scientists are trying to find the ultimate answer to the question when Greenland started to move away from North America, and what this means for the potential for oil and gas resources beneath the continental shelves of Canada and Greenland. 

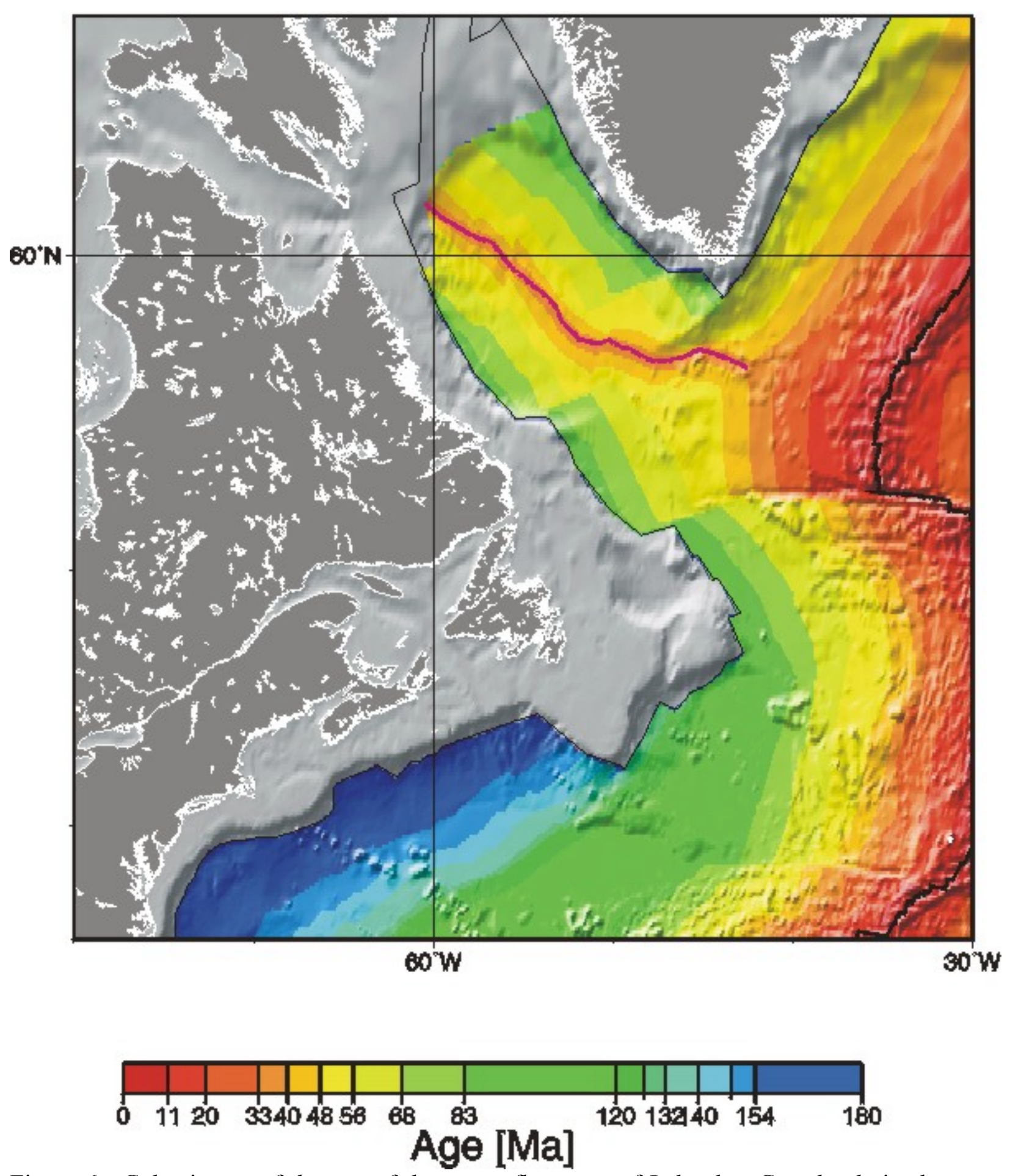

Figure 6. Color image of the age of the ocean floor east of Labrador, Canada, derived from magnetic anomalies. 


\section{Acknowledgments}

manuscript.

We thank Anne McCafferty and Viki Bankey for helpful reviews of this

\section{References}

Blakely, R.J., Wells, R.E., Tolan, T.L., Beeson, M.H., Trehu, A.M., and Liberty, L.M., 2000, New aeromagnetic data reveal large strike-slip (?) faults in the northern Willamette Valley, Oregon: Geological Society of America Bulletin, v. 112, p. $1225-1233$.

Blakely, R.J., Wells, R.E., Weaver, C.S., and Johnson, S.Y., 2002, Location, structure, and seismicity of the Seattle fault zone, Washington: Evidence from aeromagnetic anomalies, geologic mapping, and seismic-reflection data: Geological Society of America Bulletin, v. 114, p. 169-177.

Brocher, T.M., Parsons, T., Blakely, R.J., Christensen, N.I., Fisher, M.A., Wells, R.E., and the SHIPS Working Group, 2001, Upper crustal structure in Puget Lowland, Washington: Results from 1998 seismic hazards investigation in Puget Sound: Journal of Geophysical Research, v. 106, p. 13541-13564.

Cannon, W.F., Daniels, D.L., Nicholson, S.W., Phillips, J., Woodruff, L.G., Chandler, Val W., Morey, G.B., Boerboom, T., Wirth, K.R., and Mudrey, M.G, Jr., 2001, New map reveals origin and geology of North American Mid-continent Rift: EOS v. 82, p. $97,100-101$.

Committee for the Magnetic-Anomaly Map of North America, 1987, Magnetic-Anomaly map of North America: Geol. Soc. Am. Continent-Scale Map-003, scale $1: 5,000,000$.

du Bray, E. A., editor, 1996, Mineral resource potential and geology of Coronado National Forest, Southeastern Arizona and southwestern New Mexico: U.S. Geological Survey Bulletin 2083-A-K, 211 p., 32 pl

Gettings, Mark, 1999, Using textural measures of aeromagnetic data to infer lithology: International Union of Geodesy and Geophysics XXII General Assembly, 18-30 July 1999, Birmingham, U.K., Abstracts Week A, p. A390.

Gettings, Mark E., 2002, An Interpretation of the 1996 Aeromagnetic Data for the Santa Cruz basin, Tumacacori Mountains, Santa Rita Mountains, and Patagonia Mountains, South-Central Arizona: U.S. Geological Survey Open-File Report 0299. http://ge opubs.wr.usgs.gov/open-file/ofo2-9g/ 
Gettings, M.E., and Houser, B.B., 1997, Basin geology of the upper Santa Cruz Valley, Pima and Santa Cruz Counties, southeastern Arizona: U.S. Geological Survey Open File Report 97-676, 40 p., 9 figs., 6 pls.

Grauch, V.J.S., 1997, Aeromagnetic expression of intra-basinal faults in the Albuquerque basin, New Mexico, USA [abs.]: International Association of Geomagnetism and Aeronomy $8^{\text {th }}$ Scientific Assembly Abstracts, Uppsala, Sweden, p. 515.

Grauch, V.J.S., Hudson, M.R., and Minor, S.A., 2001, Aeromagnetic expression of faults that offset basin fill, Albuquerque basin, New Mexico: Geophysics, v. 66, p. 707720 .

Johnson, S.Y., Dadisman, S.V., Mosher, D.C., Blakely, R.J., and Childs, J.R., 2001, Active tectonics of the Devil's Mountain fault and related structures, northern Puget Lowland and eastern Strait of Juan de Fuca region, Pacific Northwest: U.S. Geological Survey Professional Paper 1643, 45 p., 2 pl.

Johnson, S.Y., Potter, C.J., Armentrout, J.M., Miller, J.J., Finn, C., and Weaver, C.S., 1996, The southern Whidbey Island fault: An active structure in the Puget lowland, Washington: Geological Society of America Bulletin, v. 108, p. 334354.

Lipman, P.W., and Sawyer, D.A., 1985, Mesozoic ash-flow caldera fragments in southeastern Arizona and their relation to porphyry copper deposits: Geology, v. 13, p. 652-656.

North American Magnetic Anomaly Group, 2002, Magnetic anomaly map of North America: U.S. Geological Survey Special Map, scale 1: 10,000,000.

Phillips, J.D., 2002, Processing and interpretation of aeromagnetic data for the Santa Cruz Basin; Patagonia Mountains area, south-central Arizona: U. S. Geological Survey, Report: OF 02-0098. http://geopubs.wr.usgs.gov/open-file/of02-98/

Pilkington, M., and Todoeschuck, J.P., 1993, Fractal magnetization of continental crust: Geophysical Research Letters, v. 20, no. 8, p. 639-641.

Pilkington, M., Miles, W. F, Ross, G. M., and Roest, W. R., 2000, Potential-field signatures of buried Precambrian basement in the western Canada sedimentary basin: Canadian Journal of Earth Sciences, 37, 1453-1471.

Srivastava, S.P. and Roest, W.R., 1999, Extent of oceanic crust in the Labrador Sea: Marine and Petroleum Geology, vol.16, no.1, p. 65-84.

Wells, R.E., Weaver, C.S., and Blakely, R.J., 1998, Fore-arc migration in Cascadia and its neotectonic significance: Geology, v. 26, p. 759-762. 